\title{
金属コイルおよび接着剤を用いた 気管支瘦の非手術的治療法の検討
}

\author{
渡辺 俊一, 佐藤日出夫*
}

\begin{abstract}
要 旨
気管支瘦はいったん発生すると難治性のことが多く，致死的状態に至ることさえある. 過去に非手術 的気管支瘦治療法としてフィブリン・グルーなどの接着剂による塞栓法が幾つか報告されているが, 接 着剂が脱落し失敗することが多い。これに対し著者らは，より確実な塞栓法として金属コイルを気管支 に留置したのちに接着剤を注入する方法をこれまで計 8 気管支に対して試み, 比較的良好な塞栓効果を 得てきた。 また，最長 2 年 3 カ月に执よぶ観察期間の中で本治療法に起因した合併症はみられなかっ た. 本治療法は此較的手軽に施行でき, しかも低侵襲であることから, 特に全身状態の悪化している患 者の場合には手術治療を選択する前に一度試みてもよい治療手段と考えられる.
\end{abstract}

索引用語 : 気管支瘻, コイル塞栓 bronchial fistula, coil occlusion

\section{はじめに}

気管支瘻はいったん発生すると難治性のこと が多く, 致死的状態になることもしばしばある. 特に，手術的治療に耐えられないと思われる全 身状態の悪い患者の場合，治療手段がかなり限 定されてしまう，過去に非手術的気管支瘻治療 法としてフィブリン・グルーなどの接着剤によ る塞栓法が幾つか報告され，著者らも過去に何 例か試みてきた。しかし接着剤単独による塞栓 法は，咳嗽で接着剤が吹き飛んでしまうことが しばしばある。そこで著者らは接着剤注入の前 に，金属コイルを気管支に留置することでコイ ルが接着剤の核となり，より確実な塞栓が可能 になると考光，この方法を試みて比較的良好な 成績を得てきた。本稿ではこの治療法の手技を

金沢市立病院 外科

*石川県立中央病院 呼吸器外科

原稿受付 1998年 3 月 17 日

原稿採択 1998年11月25日
紹介するとともにとの利点, 問題点についても 検討した。

\section{対 象}

塞栓の対象となったのは計 8 気管支であり， 肺癌術後の気管支断端瘻が 1 例 1 気管支, 有瘻 性膿胸の気管支瘦が 2 症例 7 気管支である (Table 1). いずれの症例も全身状態不良でか つ呼吸機能が低下している等の理由から，全身 麻酔での手術に耐えられない可能性があると考 光，十分なインフォームド・コンセントのもと に本手技を施行した。

症例 1 : 右肺下葉原発の扁平上皮癌に対して 術前放射線化学療法を施行した後, 右中下葉切 除術を行い，その中間気管支幹断端に直径約 5 mm の瘻孔を 1 力所生じた (Fig. 1).

症例 2,3 : 両者ともに有瘻性膿胸症例で開 空術が施行されて扣り, 肺表面に直径 $4 \sim 5$ $\mathrm{cm}$ の大きな瘦孔が数力所開存していた（Fig. 2). 両者とも, 開空腔内にガーゼを詰めておか ないと十分な発声がでさない位に瘻孔から大量 
Table 1 Cases of bronchial fistula receiving coil occlusion treatment.

\begin{tabular}{|c|c|c|c|c|c|c|}
\hline No. & case & disease & occluded bronchus & $\begin{array}{l}\text { occlusion } \\
\text { materials }\end{array}$ & $\begin{array}{l}\text { observation period } \\
\text { after the treatment } \\
\text { (month) }\end{array}$ & complications \\
\hline 1 & case 1 & lung cancer & $\begin{array}{l}\text { stump of the } \\
\text { truncus intermedius }\end{array}$ & coil + fibrin glue & 27 & $(-)$ \\
\hline 2 & case 2 & empyema & rt. $B^{2}$ & coil+fibrin glue & 26 & $(-)$ \\
\hline 3 & & & rt. $\mathrm{B}^{3}$ & coil + fibrin glue & 26 & $(-)$ \\
\hline 4 & & & rt. $B^{1}$ & coil+fibrin glue & 25 & $(-)$ \\
\hline 5 & case 3 & empyema & 1t. $B^{1+2} a+b$ & $\begin{array}{c}\text { coil + ECA } \\
(+ \text { Lipiodol })\end{array}$ & 6 & $(-)$ \\
\hline 6 & & & lt. $\mathrm{B}^{1+2} \mathrm{c}$ & $\begin{array}{l}\text { coil + NBCA } \\
(+ \text { Lipiodol })\end{array}$ & 6 & $(-)$ \\
\hline 7 & & & lt. $B^{3} b+c$ & $\begin{array}{l}\text { coil + NBCA } \\
(+ \text { Lipiodol })\end{array}$ & 5 & $(-)$ \\
\hline 8 & & & lt. $\mathrm{B}^{3} \mathrm{a}$ & $\begin{array}{l}\text { coil + NBCA } \\
(+ \text { Lipiodol })\end{array}$ & 4 & $(-)$ \\
\hline
\end{tabular}

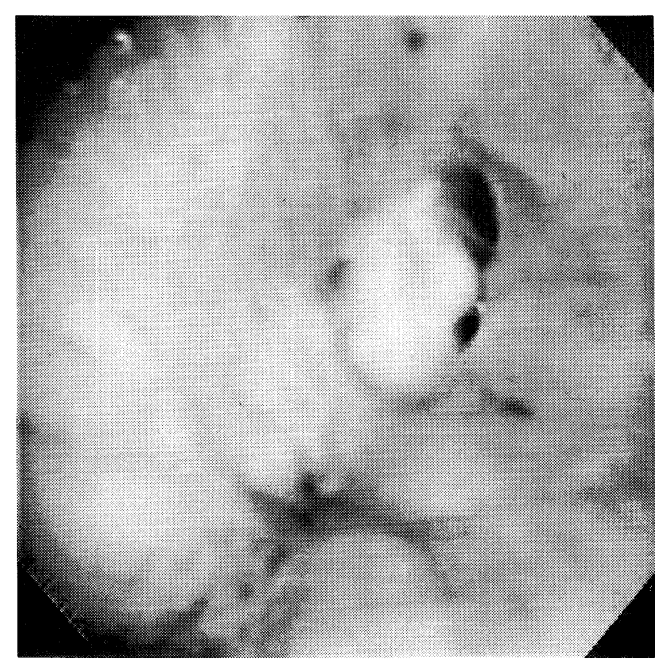

Fig. 1 Bronchoscopic photograph of the bronchial fistula of case 1 .

に空気が漏れ出る状態であった. 塞栓した㾇孔 気管支は，症例 2 が右 $\mathrm{B}^{2}, \mathrm{~B}^{3}, \mathrm{~B}^{1}$, 症例 3 が左 $\mathrm{B}^{1+2} \mathrm{a}+\mathrm{b}, \mathrm{B}^{1+2} \mathrm{c}, \mathrm{B}^{3} \mathrm{~b}+\mathrm{c}, \mathrm{B}^{3} \mathrm{a}$ の順であった (Table 1).

\section{方法}

以下に著者らの行った塞栓の手順を説明する. 1) 㾇孔の同定：まず気管支鏡下に閉塞すべき 瘦孔を同定した. 術後気管支断端瘦の場合は直

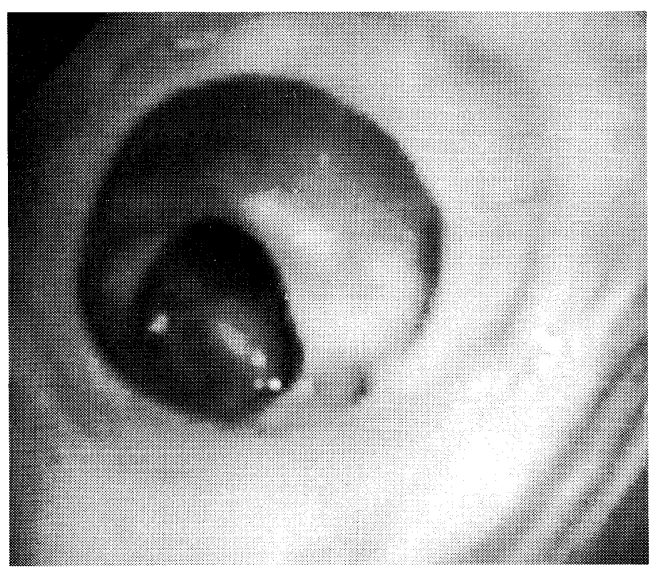

Fig. 2 Photograph of the bronchial fistula of case 3.

視できたが，有瘻性膿胸症例など瘦孔が直視不 能な場合には，水溶性造影剂を用いて塞栓する 気管支を同定した（Fig. 3).

2 ) 塞栓材料

(1)コイル：コイルは血管内塞栓用金属コイルを 用いた（OCCLUDING SPRING EMBOLIZTION COILS; MWCE-35/38, TORNADO EMBOLIZATION MICROCOILS; MWCE18S，いずれも COOK 社製) (Fig. 4).コイルは 塞栓の核となる重要な部分であり，いったん留 置したら移動することのないように，使用する 


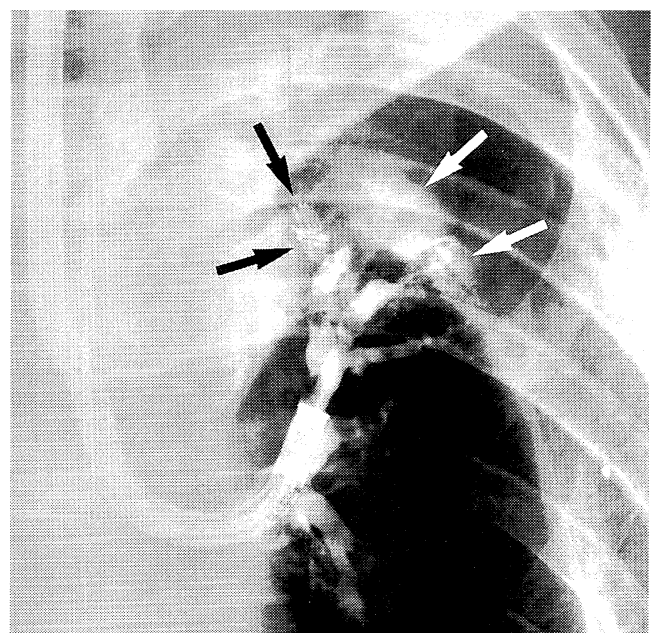

Fig. 3 Bronchography of case 3 . The $\mathrm{B}^{1+2} \mathrm{a}+\mathrm{b}$ bronchial fistula is completely occluded with coils (black arrows). The contrast medium leakes out of other fistulas (white arrows).

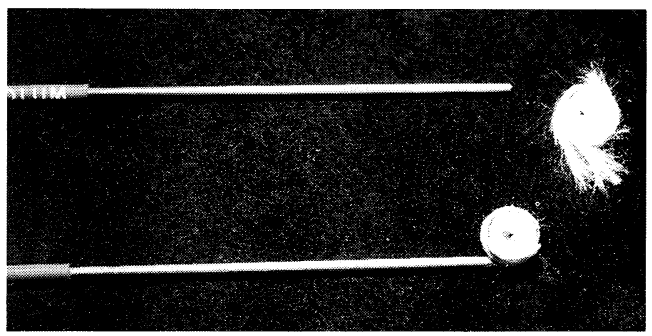

Fig. 4 Occlusion coils.

コイルのサイズをあらかじめ決定しておくこと が重要となる。そのために必要な瘦孔部分の径 の測定や, 瘦孔周用の形状の確認は気管支内視 鏡所見の汪か，3D-CT (Fig. 5) や上述した気管 支造影所見 (Fig. 3) を参考にしながら慎重に行 った。

(2)接着剤：最初の 4 気管支は金属コイルのあと にフィブリン・グルーを，次の 1 気管支には $\mathrm{ECA}$ (エチル-2-シアノアクリレート; 商品名 アロンアルファ）を，その後の 3 気管支には NBCA（n-ブチル-2-シアノアクリレートモ） マー；商品名ヒストアクリル，B. Braun Melsungen 社製）をとれぞれ注入し塞栓した

(Table 1). 症例 3 のように瘦孔が直視できな い場合は，透視下で接着剤の注入具合を確認す

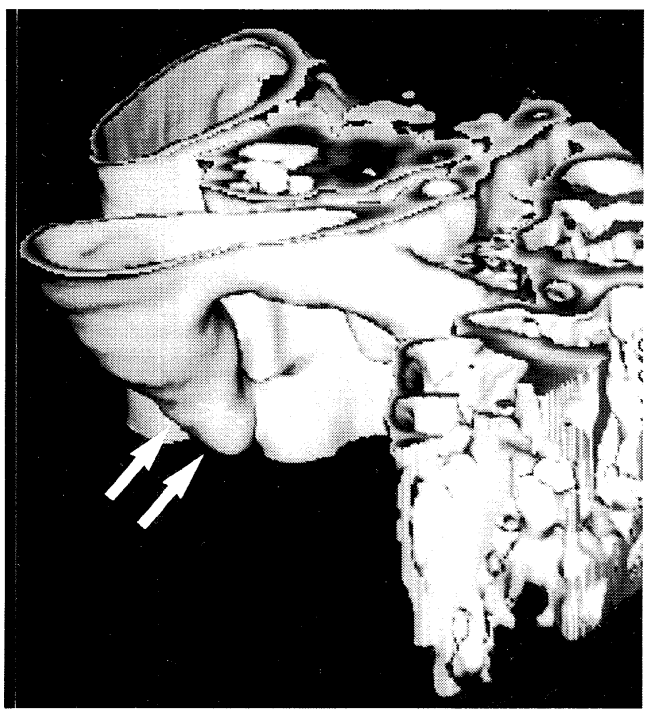

Fig. 5 Bronchial 3D-CT shows the shape around bronchial fistula of case 1 (arrows).

るため接着剂にリピオドールを混合して用いた。 これにより過剰な接着剤が正常気管支内に流入 寺ることを予防した。

3 ）塞栓の方法：気管支鏡を挿入するにあたっ ては，十分な局所麻酔薬の投与下に行うことが 重要である，手技中，接着剤が固まる前に強い 咳嗽反射が生じると，コイルの留置位置がずれ たり塞栓材料が吹き飛んだりして失敗に終わる 可能性がある。全身状態がそれ恶くなけれ ば鎮静剤も併用することが望严しい。続いて目 的の瘻孔に向けてコイル留置用のカテーテルを 気管支鏡の鉗子孔を通して挿入していく（Fig. 6). 瘦孔が小さく，マイクロコイルを使用する 場合にはそのカテーテルの内腔にさらに細いマ イクロカテーテルを挿入する二重カテーテル法 にて行った，次にコイルをカテーテルを通して 留置するが，コイルが移動して正常気管支を閉 塞するのを防止するためにコイルはやや深めに 留置した。 また，瘦孔が大きくすき間が多い場 合には最初のコイルに絡めるようにして追加の コイルを留置していった（Fig. 7)，最後に接着 剂を散布して手技を終了した。

4) 手技施行後の管理：手技施行後接着剤が完 全に固まるまでの間しばらくはベッド上安静と し，できるだけ会話を制限してコイルの位置ず 


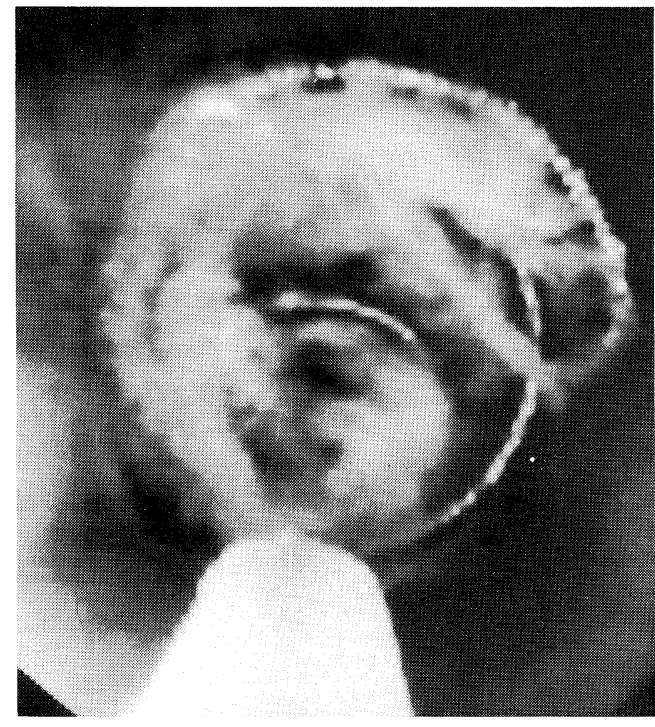

Fig. 6 Coil occlusion of bronchial fistula of case 1 through bronchoscopy.

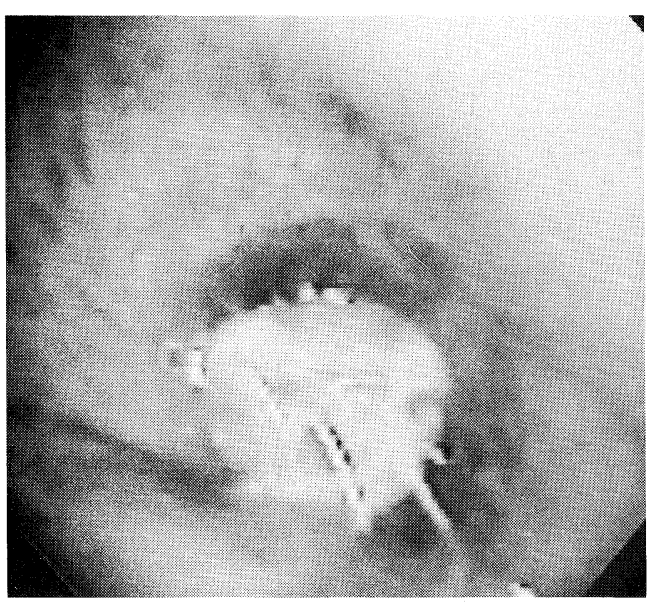

Fig. 7 Bronchoscopic photograph of the occluded bronchial fistula of case 1 .

れを防いだ。咳嗽の多い患者には鎮咳剤の投与 を行った。

5 ）その他：塞栓すべき瘦孔がいくつか存在す る場合，あるいは塞栓が完全でない場合には， 以上の手技を日を改めて繰り返し施行した．患 者の全身状態が良くない場合には，無理に 1 回 ですべての㾇孔の閉鎖を終わらせようとすると 気管支鏡挿入時間が長時間にわたるためかえっ て危険である. 手技中は必ず経鼻的酸素投与损

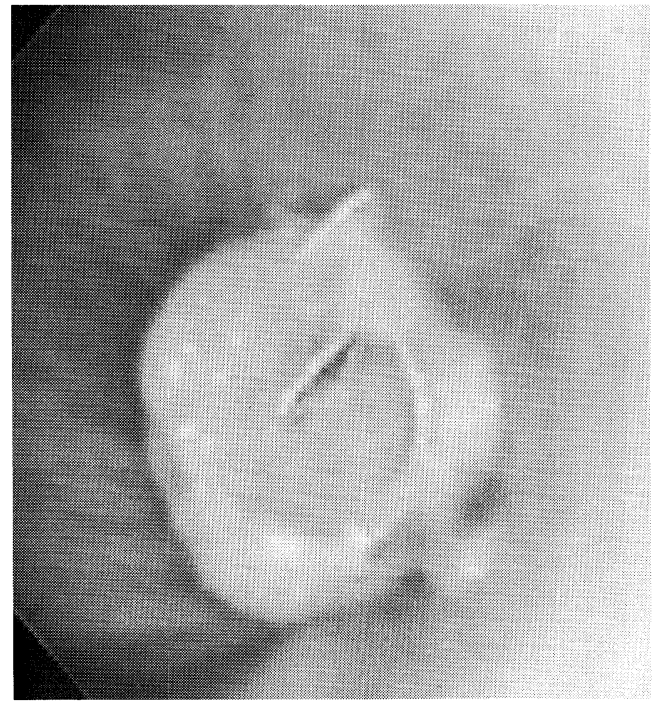

Fig. 8 Bronchoscopic photograph of the occluded bronchial fistula of case 1 four months after the treatment.

よび酸素飽和度のモニターを行った.

結果

手技中に合併症はなく，和和むね良好な結果 を得た（Fig. 8). しかし塞栓材料によって完全 に塞栓するまでの期間に差があった. コイル十 フィブリン・グルーの場合フィブリン・グルー は 2,3 日以内に脱落してしまい, 結果的にコイ ル単独と効果はほとんど変わらなかった.この 場合, 瘦孔が肉芽で完全に塞がるまでに約1.5 2 カ月間を要した. 一方，コイル $+\mathrm{NBCA}$ 使用 の場合は術直後から空気漏れが直ちに, しかも 大幅に減少し，かなり有効であるとの印象を持 った.コイル+ECA の組み合わせを施行したの は 1 回のみであるが, 塞栓効果はコイル十 NBCA と注济同様と思われた. 結局, 症例 1 で は塞栓したコイルが一度胸腔内に脱落して, 手 技を再度やり直し, 2.5 力月後に㿉孔閉鎖して退 院となった. 交た, 症例 2,3 はいずれも上記の 塞栓術にて㾇孔が閉鎖し，のちに閉空術を施行 し退院となった. 本法施行後の経過観察期間は 4 カ月から最長 2 年 3 カ月に及ぶが, 現在のと ころ本法に起因した合併症は認めていない (Table 1). 


\section{考察}

気管支瘦はいったん発生すると難治性のこと が多く, 患者管理に難渋する ${ }^{1)}$. 特に高齢者や手 術直後の患者の場合には，全身状態不良で手術 的治療法が選択できずにやがて膿胸を併発し， 敗血症や呼吸不全を生じて致死的になることが しばしばある1). なた，たと秃術が可能でも手 術的治療法が必ずしも奏功するとは限らず，い ずれにしても気管支瘦は呼吸器外科医にとって 常に頭を悩ませる病態である。

近年, 肺癌患者数は増加の一途をたどってい るが, 様々な多剂併用化学療法, 放射線同時併 用化学療法の治験や,さらにはTaxens, Camptothecin 類等の新規抗癌剂の開発, 実用 化が進んで括り，G-CSF 製剂や5-HT 阻害制 吐剂の普及と相まって進行肺癌に対する induction therapy 施行症例が増加してきている したがって, 術後気管支瘻の頻度も今後増加し ていくものと予想される.

過去に非手術的気管支㾞治療法としてフィブ リン・グルーなどの接着剂による塞栓法が幾つ

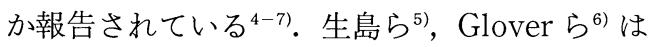
それぞれ直径 $5 \mathrm{~mm}$ 大， $4 \mathrm{~mm}$ 大の気管支瘻を フィブリン・グルーを気管支鏡下に注入するこ とによって治癒せしめたと報告しているが，フ ィブリン・グルー注入による治療症例の多くは 直径 $2 \mathrm{~mm}$ 程度の小さなものが主体である ${ }^{4)}$. 著者らもフィブリン・グルーや ECA, NBCA に よる内視鏡治療をこれまで何例か試みてきた。 しかし接着剤単独による塞栓法は, 諸家の報告 にもあるように接着剤が咳嗽によって簡単に吹 き飛び，らまくいかないことが多い(8). これに対 し舘林ら ${ }^{9)}$ は Nd-YAGレーザーによる熱凝固 を併用してフィブリン・グルーによる瘦孔閉鎖 を成功させたと報告しているが，この症例も比 較的小さな瘦孔であり，またレーザーによる出 血, 気管壁穿孔, 煙の吸引による急性呼吸不全 の発生などが危惧される 着剂注入の前に，金属コイルを気管支に留置す ることでュイルが接着剤の核となりより安全 で確実な塞栓が可能になると考え，この方法を
試みてきた。

著者らは当初, 症例 1 に示すよらにコイルを 留置したのちフィブリン・グルーを散布して塞 栓を試みた。しかし，フィブリン・グルーはす ぐに脱落することが多く，この場合は結局コイ ルのみでの塞栓となり，肉芽による完全閉鎖ま でに約 $1.5 〜 2$ 力月の期間を要するのが難点で 坊った. その後，フィブリン・グルーの代わり に ECA や NBCA どの強力な接着剤を利用 するようになりようやく即時的な効果が得られ るようになった。 また使用するコイルはFig. 4 で紹介したよらな，金属芯の回りにファイバー が付いたタイプの方がコイルの固定性がよく， かつ接着剂の絡みも良いためより有効と思われ モ.

現在までのところ本治療法に伴うトラブルは 認めていない. 本治療法の最大の利点はその低 侵襲性にめり，特に全身状態の悪い患者には最 初に試みても良い方法と思われる。本治療法は 局所麻酔下に施行でさるため, 必要に応じて繰 り返し施行することも可能である.

一方, 問題点を挙げるとすれば異物留置に伴 引感染の可能性であろら，前里ら ${ }^{10)}$ は，異物で むる接着剤は感染源となりらるものの，気管支 痽患者の場合にはすでに膿胸を合併しているこ そが多く，問題は少ないだろらと述べている.

しかし瘦孔治癒後の長期的経過に拈いても感染 の問題は残る。幸いにも自験例では症例 1 の 2 年 3 カ月を最長として，いずれの症例も現在の そころ感染の兆候は認めないが，今後症例を重 ねていく上で注意する必要はあると思われる. 京た，術直後のコイル脱落による正常気管支の 閉塞には十分注意しなければならない。そのた めには，コイル径が気管支径より小さくならな いよう, 術前検査による留置コイルのサイズ決 岀慎重に行らべきであろら。

コストの面ではコイルが上述したファイバー 付きのもので 1 個 5,500円程度，接着剤は NBCA が 1 本 3,000 円であり，手術的治療法が 選択できない患者の救命手段としては許容でき る範囲ではないかと著者は考えている。もちろ ん将来的には保険適応として明文化されること 
が望ましい。

\section{おわりに}

金属コイルと接着剂を用いた気管支瘦の塞栓 術について検討した. 本治療法は比較的手軽に 施行でき，しかも低侵襲であることから, 手術 治療を選択する前に試みてもよい治療手段と考 宫れる。

謝辞：本稿を終えるにあたって，ご協力いた だきました金沢市立病院放射線科の上田隆之先 生, 同外科の橋爪泰夫先生, 永里敦先生ならび に石川県立中央病院放射線科の清水博志先生に 深謝いたします。

\section{文献}

1）佐藤雅美, 斉藤泰紀, 藤村重文, 他：最近の術 後気管支断端癭例の検討一診断上の問題点と 早期再手術による治療成績について一. 日胸外 会誌 37：11-16, 1989.

2）片上信之, 松本久子, 富岡洋海, 他: 非小細胞 肺癌 III 期症例飞対する集学的治療の短期治療 成績. 癌と化療 $22: 531-537,1995$.
3) Macchiarini P, Chapelier AR, Monnet I, et al: Extended Operations After Induction Therapy for Stage III b (T4) Non-Small Cell Lung Cancer, Ann. Thorac. Surg. 57 : 966973, 1994.

4) 平尾素宏, 島田 守, 金子 正, 他: 内視鏡下 フィブリン糊治療が有効であった食道㿉の 2 症例. 日胸外会誌 $42: 2144-2149,1994$.

5）生島義久, 渡辺智仁, 船井哲雄, 他：フィブリ ン糊による術後気管支瘦の内視鏡的治療. 日胸 外会誌 $36: 2521-2524,1988$.

6) Glover W, Chavis TV, Daniel TM, et al: Fibrin glue application through the flexible fiberoptic bronchoscope : Closure of bronchopleural fistulas. J Thorac Cardiovasc Surg 93: 470-472, 1987.

7) Jones DP, David I: Gelform Occlusion of Peripheral Bronchopleural Fistulas. Ann Thorac Surg 42: 334-335, 1986.

8）桐山昌伸, 山川洋右, 丹羽 宏: 肺切除後気管 支瘦治療法の検討. 気管支学 $15: 850-852$, 1993.

9）舘林孝幸, 大貫恭正, 神楽岡治彦, 他 : Nd-YAG レーザー及びフィブリングルーによる内視鏡 的瘻孔閉鎖術にて治癒した肺癌術後気管支断 端瘦の 1 例. 日呼外会誌 $8: 710-716,1994$.

10）前里和夫，川畑 勉，国吉真行，他：経気管支 的に㾞閉鎖を行った術後気管支㾇の 1 治験例. 気管支学 $10: 438-442,1988$.

\section{Coil occlusion method for treatment of bronchial fistula}

\section{Shun-ichi Watanabe and Hideo Sato*}

Department of Surgery, Kanazawa Municipal Hospital and *Department of Thoracic and Cardiovascular Surgery, Ishikawa Prefectural Central Hospital, Kanazawa, Japan

Bronchial fistula is one of the major complications after lung surgery, and remains a serious disorder associated with high mortality. Recently it is reported that some types of the neoadjuvant chemotherapy or concurrent chemoradiotherapy are effective for advanced lung cancer using G-CSF agents. Such patients, however, have a high incidence of bronchial fistula after surgery. Usually surgical operation is performed for treatment of the bronchial fistula only when the patient is considered able to tolerate general anesthesia. We report here that coil occlusion method through bronchoscopy effectively treated bronchial fistula without surgical stress. This suggests that coil occlusion method could be of therapeutic benefit in life-threatening bronchial fistula especially in poor risk patients. 